\title{
University-linked programmes for sustainable entrepreneurship and regional development: how and with what impact?
}

\author{
Marcus Wagner • Stefan Schaltegger • Erik G. Hansen • Klaus Fichter
}

Accepted: 17 June 2019 / Published online: 11 November 2019

(C) The Author(s) 2019

\begin{abstract}
State universities are increasingly being transformed from institutions with traditional teaching and research responsibilities to have a third, societal role in sustainable regional and economic development. In doing so, universities support knowledge spillovers to improve sustainable entrepreneurial ecosystems that benefit economic revitalization or further development of regions. At the same time they promote stakeholder involvement in crucial governance processes at the regional level. Based on a comparative case study design building on three cases in Germany, our research analyses these interdependencies focussing on university-linked support programmes for sustainable entrepreneurship and the effects on sustainable regional development. Our findings provide a nuanced view clarifying the different roles universities have, how knowledge spillovers are created,
\end{abstract}

\footnotetext{
M. Wagner $(\bowtie)$

University of Augsburg \& Bureau d'Economie Théorique et Appliquée, Universitätsstr. 16, 86159 Augsburg, Germany e-mail: marcus.wagner@wiwi.uni-augsburg.de

S. Schaltegger

Leuphana University Lüneburg, Centre for Sustainability

Management (CSM), Lüneburg, Germany

E. G. Hansen $(\bowtie)$

Johannes Kepler University Linz (JKU), Institute for Integrated Quality Design (IQD), Altenberger Strasse 69, A-4040 Linz, Austria

e-mail: erik.hansen@jku.at

K. Fichter

Carl von Ossietzky University Oldenburg \& Borderstep Institute for Innovation and Sustainability, Oldenburg, Germany
}

and what outputs, outcomes, and effects are realized at the regional level and beyond. Specifically, we demonstrate that depending on the regional context, different configurations, pathways, and intervention points of universities may equally improve sustainable entrepreneurial ecosystems.

Keywords University · Support · Programmes ·

Sustainable · Entrepreneurship · Regional ·

Development $\cdot$ Innovation $\cdot$ Facilitation $\cdot$ Sustainability Ecopreneurs $\cdot$ Start-ups

JEL classification $\mathrm{L} 26 \cdot \mathrm{O} 12 \cdot \mathrm{Q} 01$

\section{Introduction}

As part of a longer-term global trend, state universities in Germany are being transformed from institutions focussing on teaching and research to increasingly assume a third role in sustainable regional and economic development (Etzkowitz and Leydesdorff 2000; Abreu et al. 2016). In doing so, they are conceived to much more strongly support knowledge spillovers and as part of this also to promote stakeholder involvement in governance processes at the regional level. They potentially will play a far more important role in economic revitalization or further development of regions. Because large-scale and comprehensive societal transitions towards sustainability are considered to be fundamentally knowledge-driven, this also implies a significantly heightened role for universities in sustainable regional development (Sedlacek 2013). 
Concerning multi-stakeholder governance and knowledge transfers in the entrepreneurship context, the knowledge spillover theory of entrepreneurship (Agarwal et al. 2007, 2010) and notions of entrepreneurial ecosystems and innovation systems (Markard and Truffer 2008; Audretsch and Berlitski 2013; Stam 2015; Theodoraki et al. 2018) play a key role. Both of these stress that knowledge investments by firms and universities need to be linked to entrepreneurial activities so that knowledge spillovers result in a win-win situation in a wider ecosystem (Agarwal et al. 2007).

In our study, we focus the analysis on how university-related support programmes for entrepreneurship contribute to sustainable development of regions in terms of supporting a balance of economic and socio-ecological benefits in the region (e.g. Cohen and Winn 2007; Wagner and Schaltegger 2010). We relate this to the role of universities in supporting knowledge spillovers in the entrepreneurial ecosystems and innovation systems of the region they are in (Stam and Spigel 2016). Given that those universities are usually public sector organizations, they have a comparatively greater propensity to be at least to some extent embedded in a region owing to their third role mentioned above.

Our research follows a comparative case study design (Yin 2003). Two units of analysis are applied: the university-linked support programme and effects on sustainable regional development. These are related to the knowledge spillover theory of entrepreneurship (Agarwal et al. 2007, 2010), different functions in entrepreneurial ecosystems and innovation systems (Stam and Spigel 2016; Markard and Truffer 2008) and a differentiation of effects based on the theory of change (Carman 2010; Funnel and Rogers 2011; McLaughlin and Jordan 1999).

For reasons of comparability and comprehensiveness, three cases in Germany were selected, namely an incubator, an entrepreneurship education module, and a sustainability education program. These were analysed comparatively in order to clarify the university links of each initiative and how it generated knowledge spillovers and involved public actors, as well as what kind of public good was delivered. Our study thus contributes to providing a more differentiated view of how to implement entrepreneurial and innovation-oriented strategies for social sustainability and protecting the natural environment through different configurations of universityrelated knowledge spillover mechanisms. In the remainder of the paper, we next review the relevant literature and condense it into a conceptual model that can guide our analysis (Section 2). We then detail our chosen method including the procedure applied to generate our sample, the data collection processes and the analysis strategy (Section 3). Subsequently, we present our empirical material in detail on a case-by-case basis (Section 4). Following this, we present the results of our analysis based on a case comparison (Section 5). The paper finishes with a discussion and some overall conclusions (Section 6).

\section{Literature review and conceptual considerations}

2.1 Universities as actors in the knowledge economy: the knowledge spillover theory of entrepreneurship

While traditionally governments have played a dominant role in fostering knowledge diffusion, universities have become increasingly important contributors to that task. The university has been transformed from a pure teaching institution via the Humboldtian notion of combining teaching and research to one that increasingly takes on a third, societal role in regional and economic development by supporting and creating knowledge spillovers (Etzkowitz and Leydesdorff 2000; Agarwal et al. 2010) into the regions where they are situated (Etzkowitz and Klofsten 2005). The triple helix model linking teaching, research and development has gained importance as an analytical device for studying this development (e.g. Etzkowitz and Leydesdorff 2000). Similarly, the knowledge spillover theory of entrepreneurship helps to understand how this shapes entrepreneurial ecosystems and innovation systems (Agarwal et al. 2007; Audretsch and Berlitski 2013). For example, regional governments and universities cooperate to establish and operate incubators in which social or environmental entrepreneurs are supported (Cohen 2006). In this paper, we focus on the role of universities in entrepreneurial ecosystems from a knowledge-based view building on the knowledge spillover theory of entrepreneurship (Agarwal et al. 2007) and the notion that the entrepreneur is the primary conduit of transmitting knowledge spillovers (Audretsch and Berlitski 2013). We consider the process of new knowledge commercialization through knowledge spillover as a key determinant of innovation and growth in industries and regions (Audretsch and Berlitski 2013) as well as a 
potential factor for sustainable development within a region (Simatupang et al. 2015).

2.2 Functions and effects of entrepreneurial ecosystems: the role of universities in facilitating sustainable entrepreneurship

'Entrepreneurial universities', which emphasize their role in regional economic development next to the more traditional role in teaching and research, are an important element of (regional) innovation systems (Rothaermel et al. 2007) and entrepreneurial ecosystems (Theodoraki et al. 2018). The concept of innovation systems and the entrepreneurial ecosystems approach are helpful in investigating and explaining the role of university-related support programmes for entrepreneurship and their effects on the sustainable development of a region. Both concepts focus on the external business environment and emphasize that there are forces beyond the boundaries of an organization, but within those of a region, that can contribute to a firm's overall competitiveness and impacts (Stam and Spigel 2016). Besides similarities, there are also differences between the concepts, for example, with regard to the role of knowledge: While the concept of innovation systems emphasizes the importance of knowledge spillovers from universities and other large researchintensive organizations, the approach of entrepreneurial ecosystems stresses the crucial role of entrepreneurial knowledge in the innovation process (Stam and Spigel 2016). Our investigation can benefit from both concepts, and accordingly, we build on both.

An entrepreneurial ecosystem can be defined as 'a dynamic community of interdependent actors (entrepreneurs, suppliers, buyer, government, etc.) and systemlevel institutional, informational and socioeconomic contexts' (Audretsch and Belitski 2017: 1034). With regard to the units of analysis of our investigation (the university-related support programme and outputs and outcomes for sustainable regional development), two aspects of entrepreneurial ecosystems are especially relevant: (1) What functions can they provide for sustainable entrepreneurship? and (2) What effects are relevant from the viewpoint of sustainable regional development? Entrepreneurial ecosystems and in a similar fashion innovation systems provide different 'functions' to the actors embedded in them (Markard and Truffer 2008; Audretsch and Berlitski 2013; Stam 2015; Theodoraki et al. 2018). These include knowledge development and diffusion, provision of education and training, entrepreneurial experimentation, incubation activities, financing of innovation processes, provision of consultancy and networking and interactive learning, as detailed in Table 1.

With regard to the potential effects entrepreneurial ecosystems and especially universities can trigger, we apply a regional perspective on sustainable development and relate it to the concept of sustainable entrepreneurship.

Of course, sustainable development cannot be addressed from a regional perspective alone, as many sustainability issues such as climate change are global phenomena. Another issue is that regional sustainable development could have a negative impact on or divert opportunities from other regions. For example, the former is the case when 'dirty' value chain activities are relocated from developed to developing countries. The latter is about the loss of business and development opportunities in one region due to regional sourcing and production practices in another region, such as in the case of locally sourced, low-carbon goods versus internationally sourced fair-trade goods (Holt and Watson 2008). Nevertheless, the advantages regarding the stronger identification of actors include increased political accountability and improved means of implementation which justify a regional focus (Thierstein and Walser 1997). Furthermore, global phenomena relating to unsustainability must also be addressed by activities and partial solutions in local contexts. Looking at sustainable development from a regional perspective, next to conventional economic effects such as job creation

Table 1 Functions of entrepreneurial ecosystems and innovation systems (based on Markard and Truffer 2008: 602)

Functions of entrepreneurial ecosystems and innovation systems

- Provision of education and training

- Knowledge development and diffusion

- Provision of R\&D

- Influence on the direction of search

- Entrepreneurial experimentation

- Incubation activities

- Resources mobilization

- Financing of innovation processes

- Market formation

- Creation of legitimacy

- Networking and interactive learning

- Provision of consultancy

- Creation/change of institutions 
and deceleration of the 'rural exodus', we need to consider potentially wider effects such as reduced carbon footprints, healthier jobs and better opportunities for disadvantaged groups, in addition to improved regional stakeholder integration and governance.

Sustainable entrepreneurship is a new research field that is still developing. Since 2009, the number of articles published on sustainable entrepreneurship has increased significantly (Binder and Belz 2015; Gast et al. 2017). While many of these articles emphasize opportunityseeking as being key to sustainable entrepreneurship, another important thread of literature highlights a creative and effectuation-based approach (Hockerts and Wüstenhagen 2010; Parrish 2010; Schaltegger and Wagner 2011) that adopts a creation perspective. Such research emphasizes the active role of ecopreneurs and sustainable entrepreneurs in creating sustainabilityoriented change (Schaltegger et al. 2016; Boons et al. 2013). This perspective is particularly important for a creative view of universities supportive of sustainable entrepreneurship. In this paper we view sustainable entrepreneurship, in accordance with Pacheco et al. (2010), as the discovery, creation, evaluation and exploitation of opportunities to create innovative goods and services that are consistent with regional, national and sustainable development goals (United Nations General Assembly 2015; Schaltegger et al. 2018). Creating, recognizing and taking advantage of sustainable opportunities are complex challenges for sustainable entrepreneurs and demand specific support systems. An effective support system incorporates all actors, institutional settings and resources that help entrepreneurs in innovating successfully (Fichter et al. 2016). In this paper, we concentrate on the university as an important supporting actor. We assume that, on the one hand, some personal attributes of entrepreneurs such as the individual's prior knowledge and motivation (Shepherd and Patzelt 2011), sustainability orientation (Kuckertz and Wagner 2010; Wagner 2012) and perpetual reasoning (Parrish 2010) can be influenced by the knowledge spillovers they receive within the university context. On the other hand, universities are also able to support external economic actors like SMEs or start-ups in developing and establishing sustainable and often technology-driven products through their research and development $(\mathrm{R} \& \mathrm{D})$ resources (Abdelkafi and Hansen 2018).

\subsection{Theory of change}

Our research investigates how (entrepreneurial) universities and the different forms of knowledge spillovers they create can foster sustainable entrepreneurship that impacts sustainable regional development. Given the key role of universities, which are often non-profit organizations, and the emphasis on ultimate impacts, our analysis draws on logic models and the closely-linked concept of a theory of change which serves a prominent programme evaluation role in the non-profit sector (Funnel and Rogers 2011; Carman 2010). The theory of change draws on defining linear cause-and-effect chains from programme implementation to societal impact (McLaughlin and Jordan 1999). Similar models are used in the context of corporate philanthropy (e.g. London Benchmarking Group 2004), corporateNGO partnerships (Hansen et al. 2010; Hansen and Spitzeck 2011) and in performance measurement in the area of corporate sustainability (Epstein and Roy 2001; Hansen and Schaltegger 2016) and start-up venturing (Ney et al. 2014). Notably, a logic model or, taking a narrative perspective, a theory of change assumes a linear causality between inputs, activities, (immediate) outputs, outcomes and impacts as is detailed in Fig. 1.

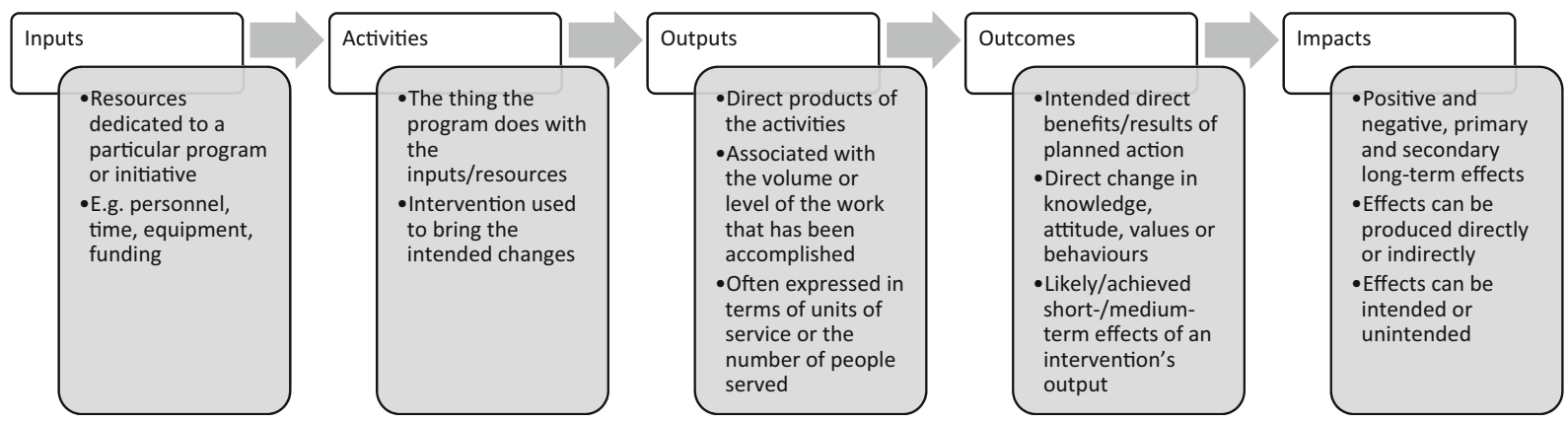

Fig. 1 Theory-of-change framework formulating a logic model (based on Carman 2010; OECD 2002) 
We maintain that the theory of change can be fruitfully applied to analyse effects of entrepreneurial ecosystems. By this logic, the entrepreneurial ecosystem model provided by Stam and Spigel (2016) includes the consideration of outputs (entrepreneurial activity) and outcomes (aggregated value creation) of conditions such as knowledge and support services in entrepreneurial ecosystems. While the linear logic has been used widely and contributes to a straightforward analytical understanding, it also represents an approximation of cause and effect chains existing in reality. It is also based on the assumption that developing universities, creating educational programmes, teaching students, developing entrepreneurs, and facilitating new ventures ultimately matter and generate impact in the larger system. But identifying or even measuring effects from one to the next logical step becomes harder (and more resourceintensive) the more we move from left to the right. Finally, while this linear logic model can only cover the most important causalities, other iterative or non-linear relationships could be neglected. However, by covering these most important causalities, the linear logic we apply appears a good first approximation for our research question.

\subsection{Conceptual framework and guiding research questions}

The review of three interrelated literatures leads us to propose the following (preliminary) conceptual framework (Fig. 2). The framework has four overarching components (which are italicized in Fig. 2): first, the basis of the framework is the knowledge spillover theory of entrepreneurship describing the process from investments by established organizations into knowledge creation, the take-up of entrepreneurial action leading to new ventures, and how their performance ultimately leads to growth of industries and regions. Second, the theory of change helps us to generalize the latter knowledge spillover process into a logic model from inputs to impacts. Third, the entrepreneurial ecosystems' view stresses that the success of entrepreneurs is influenced by how conducive the embedding system is, consisting of various actors, fulfilling diverse functions, generating various

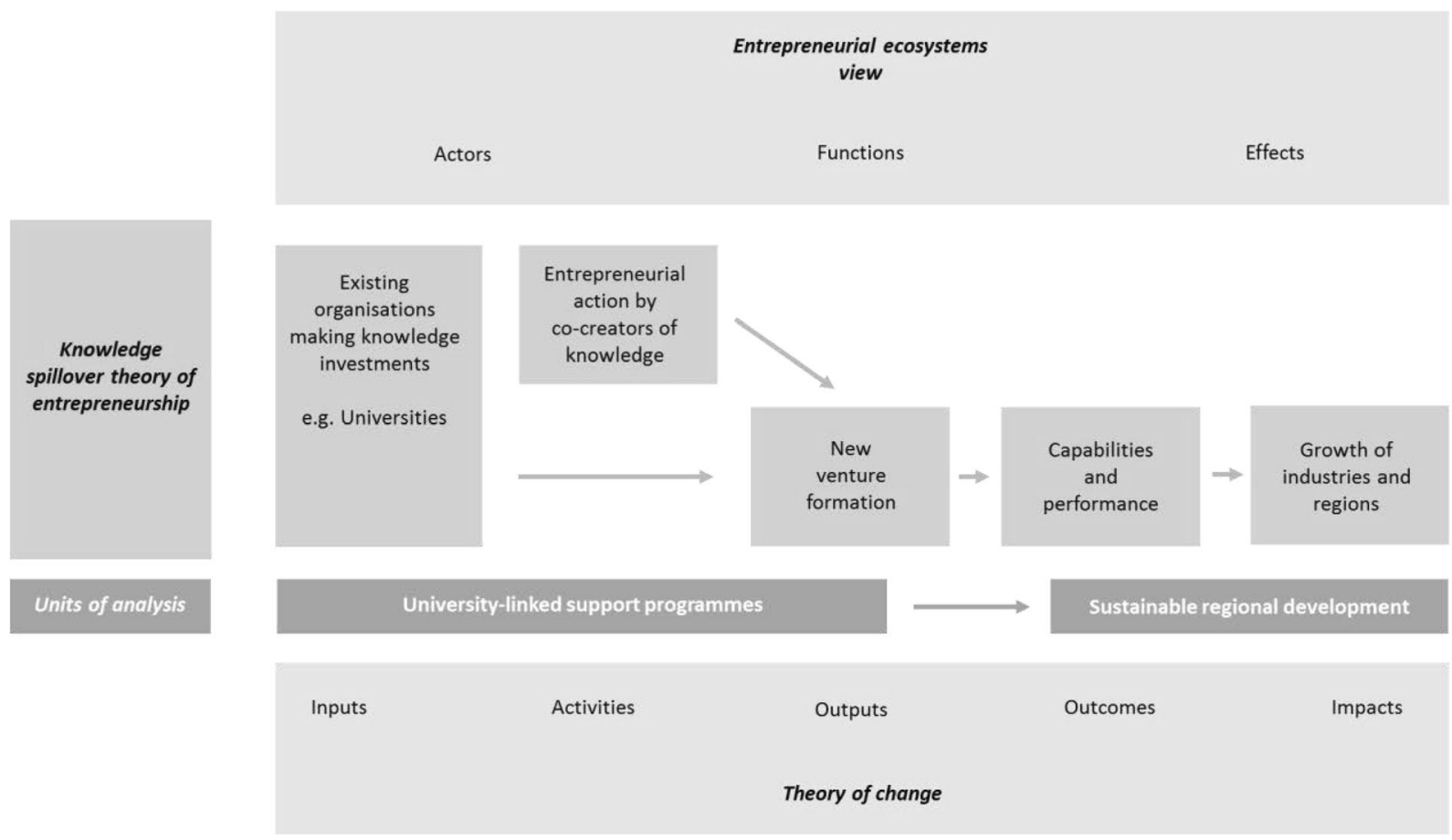

Fig. 2 Framework for investigating the role of university-linked support programmes for sustainable regional development (based on Agarwal et al. 2007: 267; Carman 2010) 
effects. Fourth, the unit of analysis highlights that, by covering the entire process from inputs to impacts, we actually cover two units of analysis: inputs to outputs occur in the realm of the university-linked support programmes, while outcomes and impacts relate to the larger system in the sense of sustainable regional development.

Based on the above framework, our main research questions are:

(1) How do university-linked programmes support sustainable entrepreneurship?

(2) How do university-linked programmes contribute to:

(a) an improvement of the entrepreneurial ecosystem for sustainable entrepreneurship?

(b) entrepreneurial activities by sustainable entrepreneurs?

(c) the overall sustainable development in the region?

\section{Method}

\subsection{Research design and sample}

Our research uses a multiple embedded case study design (Eisenhardt 1989) following literal replication (Yin 2003). Two units of analysis are applied: the support programmes and the resulting ventures (outcomes) with their impacts for the region. Overall, we selected three cases (Table 2) according to the following criteria:

- All are located in the same country to control for the national institutional context. We chose Germany, because sustainability is often valued highly and because it has established extensive support structures for entrepreneurs and many successful sustainable entrepreneurship-related programmes over the last two decades (Fichter et al. 2016; Bank et al. 2017). To increase comparability even further, this paper studies three cases from the two largest German states-Bavaria and Lower Saxony-which are the most similar in the federal context of Germany. Universities in these two states were screened for involvement in well-known entrepreneurial sustainability initiatives while case selection continued until theoretical saturation was achieved to find distinct cases for further analysis.

- Programmes have been established for at least 10 years and all are pioneers on the European or global levels (e.g. MBA Sustainability Management as the world's first MBA programme with a sustainability focus; UTG Augsburg was the first sustainability-specific incubator in Europe, EcoVenturing was the first course worldwide with students developing sustainability-orientated business concepts in cooperation with business partners aiming to promote tangible green business startups). This sufficiently long case history allows us to assess the impacts on sustainable regional development.

- All cases have been publicly acknowledged to be successful (e.g. through receiving awards or high levels of funding or visibility).

- In all cases, the university (possibly in combination with other research-oriented institutions) played a major role in facilitating sustainable entrepreneurship.

- The researchers had very good data access (Yin 2003).

Overall, our cases can be classified as 'unique' (Yin 2003) as they cover university-based or related facilitation of sustainable entrepreneurship in long established (successful) pioneer programmes. The cases are also 'revelatory', because the unusually good access by the researchers facilitated the study of previously unaddressed aspects (Yin 2003). The unusual level of access stems from the fact that in all cases, researchers have been involved either in the programme's foundation and operation, or in research on and consultation with the case entity.

Despite the similarities described above, we also deliberately encouraged diversity among the cases to better reflect the nature of the present exploratory work that aims to deliver a better understanding of a new phenomenon. As shown in Table 2 (in chronological order), we included different types of programmes that also cover different phases in the entrepreneurial process (Shane and Eckhardt 2003). Covering such heterogeneity has intrinsic value as it represents the diversity of approaches taken by institutions to facilitate sustainable entrepreneurship. Moreover, despite their differences in type, the nature of the outcomes highlighted in our 
Table 2 Case characteristics

\begin{tabular}{|c|c|c|c|}
\hline Case & $\begin{array}{l}\text { Institutions/ } \\
\text { university }\end{array}$ & $\begin{array}{l}\text { Programme } \\
\text { start }\end{array}$ & $\begin{array}{l}\text { Type of } \\
\text { programme }\end{array}$ \\
\hline $\begin{array}{l}\text { UTG } \\
\text { Augsburg }\end{array}$ & $\begin{array}{l}\text { State of } \\
\text { Bavaria, } \\
\text { Chambers, } \\
\text { University of } \\
\text { Augsburg }\end{array}$ & 1998 & Incubation \\
\hline $\begin{array}{l}\text { MBA } \\
\text { Sustainability } \\
\text { Mana gement }\end{array}$ & $\begin{array}{l}\text { Leuphana } \\
\text { University } \\
\text { Lüneburg }\end{array}$ & 2003 & $\begin{array}{l}\text { Education } \\
\text { (full-degree } \\
\text { programme) }\end{array}$ \\
\hline Eco-Venturing & $\begin{array}{l}\text { Carl von } \\
\text { Ossietzky } \\
\text { University } \\
\text { Oldenburg }\end{array}$ & 2009 & $\begin{array}{l}\text { Entrepreneurship } \\
\text { education (single } \\
\text { module), start-up } \\
\text { facilitation }\end{array}$ \\
\hline
\end{tabular}

analysis (i.e. the creation of sustainable ventures) is comparable (please note that we are not primarily interested in comparing the quantity of outcomes/ventures, which certainly differ between more conventional incubators and teaching-based programmes).

\subsection{Data collection and analysis strategy}

We collected data from multiple sources covering both secondary and primary data. The secondary data on the selected support programmes (e.g. Hesselbarth et al. 2015; Wagner and Lutz 2012; Fichter et al. 2016) helped us to obtain both a broad understanding of the programmes and details of the programme design, participation and outcomes. Primary data covered participant observation, workshops, interviews, and desk research. We also collected data at multiple points in time (longitudinal case). Overall, this permitted the extensive triangulation of information that was supplemented with informal data, wherever possible. Following Miles and Huberman (1994), we stopped collecting further data when new aspects on the issues captured by our research questions could no longer be identified. Table 3 provides an overview of this process and the resulting data sources.

As suggested by Eisenhardt (1989), the data analysis was carried out as an iterative process between literature and data. We started with broad concepts from literature that we found informative for the case study focus (e.g. theory of change). We then collected single case descriptions for all our cases. Frequent group discussions within the research team helped to develop a common understanding of both deductive and emerging categories. Following this, we carried out a comparative analysis across cases, which according to Glaser and Strauss (1967) is appropriate when theoretical saturation is reached. In the remainder of the paper, we reflect this process by initially introducing in the following section the individual cases.

\section{Case studies}

This section introduces the three cases of support programmes and related venture creations that form the basis for the detailed analysis. Each case description includes information on the context of the programme and its relevant inputs, outputs, outcomes and impacts. To provide further insights into and evidence of impacts generated through the three cases, we then scrutinize one start-up for each case to clarify how the programmes led to or supported the founding activities of specific entrepreneurial individuals.

\subsection{Case 1: UTG Augsburg}

\subsubsection{University-linked support programme}

In 2006, the state of Bavaria collaborated with local universities to support certain future technology domains. The aim was to employ a cluster programme involving networking and cross-linking of technology-oriented and technology-specific business incubators and technology centres. One of the domains focussed upon was environmental technology. The concept thus built on the cluster logic and agglomeration economies (Marshall 1920; Porter et al. 2010). The UTG Augsburg was a core element in the cluster programme and the only business incubator specializing in environmental technology supported by the Bavarian state. It was set up in 1998 and in fact was the only incubator in the EU with such a specialization at that time (Hehl 2010). The major mobilization of resources was through leveraging funds made available through the Bavarian cluster programme, which provided a window of opportunity and a rare chance to develop a dedicated incubator. Furthermore, prior knowledge and experience resided in the local universities and a local 
Table 3 Data collection

\begin{tabular}{|c|c|c|c|}
\hline & Case 1: UTG Augsburg & $\begin{array}{l}\text { Case } 2 \text { : MBA Sustaina bility } \\
\text { Management }\end{array}$ & Case 3: Eco-Venturing \\
\hline Secondary data & $\begin{array}{l}\text { - Presentation on the Bavarian cluster } \\
\text { strategy and the centre (Hehl 2010; } \\
\text { Wagner and Lutz 2012) } \\
\text { - Presentation on environmental } \\
\text { technology incubation at the centre } \\
\text { (Hehl 2011) } \\
\text { - Evaluation report on environmental } \\
\text { technology and energy in Bavaria } \\
\text { (Anon. 2011) }\end{array}$ & $\begin{array}{l}\text { - Alumni survey on skills and } \\
\text { career path (Hesselbarth and } \\
\text { Schaltegger 2014) } \\
\text { - Programme foundation and } \\
\text { institutional change (Lee and } \\
\text { Schaltegger 2014) } \\
\text { - Programme's teaching } \\
\text { pedagogies and skill } \\
\text { development (Hesselbarth } \\
\text { et al. 2015) }\end{array}$ & $\begin{array}{l}\text { - Case study analysis of university } \\
\text { support structures and programmes } \\
\text { (Geier and Fichter 2015) } \\
\text { - Interview with responsible teaching } \\
\text { personnel (Fichter et al. 2016) }\end{array}$ \\
\hline \multicolumn{4}{|l|}{ Primary data: } \\
\hline $\begin{array}{l}\text { - Desk research and } \\
\text { internal data }\end{array}$ & $\begin{array}{l}\text { - Programme websites } \\
\text { - Venture websites and media } \\
\text { contributions }\end{array}$ & $\begin{array}{l}\text { - Programme websites } \\
\text { - Venture websites and media } \\
\text { contributions } \\
\text { - Student database, teaching } \\
\text { evaluations, alumni surveys }\end{array}$ & $\begin{array}{l}\text { - Programme websites } \\
\text { - Venture websites and media } \\
\text { contributions } \\
\text { - Student, alumni and start-up } \\
\text { database, venture survival analysis } \\
\text { and impact evaluation }\end{array}$ \\
\hline $\begin{array}{l}\text { - Participant } \\
\text { observation, } \\
\text { workshops, and } \\
\text { interviews }\end{array}$ & $\begin{array}{l}\text { - Interview with past centre manager } \\
\text { - Interviews with nine start-ups from } \\
\text { the centre } \\
\text { - Interview with current centre manager }\end{array}$ & $\begin{array}{l}\text { - } 520 \text { days of programme } \\
\text { development } \\
->600 \text { days of own teaching } \\
\text { - } 100 \text { days of further programme } \\
\text { participation } \\
\text { - Two workshops with } \\
\text { sustainable ventures }\end{array}$ & $\begin{array}{l}\text { - } 80 \text { days of programme development } \\
\text { - } 120 \text { days of teaching } \\
\text { - } 240 \text { days of student coaching } \\
\text { - Five interviews with participating } \\
\text { students and start-up-entrepreneurs }\end{array}$ \\
\hline
\end{tabular}

research institute, the Bavarian Institute for Waste Research.

The UTG mainly covers the innovation system functions of experimentation, incubation, resource mobilization and networking. The latter is extended through the interaction of partners that also provide extended support functions. Specifically, the 'Umweltcluster Bayern' (of which the UTG is a main member) is itself a member of a Europe-wide network of environmental technology clusters named 'EcoCluP', which incorporates over 3500 firms and 430 research institutions from ten EU countries (Anon. 2011). Furthermore, the UTG is a major partner in the 'Kompetenzzentrum Umwelt e. V.' (abbreviated to KUMAS, a network of Bavarian environmental technology firms headquartered at the UTG). The UTG hosts an average of 40 start-up firms for an average of 4.7 years, during which time they benefit from below-average rental rates and flexible contract conditions among other cost advantages.

Assessing the regional sustainability impact of the innovations realized by the start-ups that have been in the incubator involves evaluating environmental contributions. The process includes life-cycle assessments that individual entrepreneurs in the incubator already use as a communication tool. Economically and socially the regional impact is mainly generated through around 200 jobs created and over 30 patents granted in the 140 firms incubated since 1998 (Hehl 2011; Anon 2018).

\subsubsection{Exemplary new venture}

The start-up Corrmoran was founded as a University of Augsburg spinoff and joined the UTG in 2008. The four founders (three of whom came from the university) initially also received support by the university in the form of an EXIST (German federal initiative for academic start-ups) grant for developing their venture's business plan. Corrmoran developed a new sensor device, which made it possible to measure the corrosion in large-scale firing plants online during operation. The initial development of the device resulted from a research project at the university supported by the European Regional Development Fund. Corrosion of heat exchangers is one of the main factors limiting energy efficiency and creates huge maintenance costs in large-scale 
firing plants. Early detection of corrosion issues using Corrmoran's sensor can improve energy efficiency and deliver cost savings, which are likely to make a significant impact on regional and global sustainability. Corrmoran has also won several business plan competitions such as the regional "BPWSchwaben" in 2008 and the second stage of the Munich Business Plan Competition (MBPW) in 2009, and has placed second in the Marathon category of the third stage of the MBPW. The environmental credentials of Corrmoran's product have been recognized by the project becoming one of the three official model projects which represent the best environmental competencies in Bavaria. The technology developed by Corrmoran has high potential as certified by the fact that the "High-Tech Gründerfonds" (a public-private partnership between the German Government and several leading German multinationals from different industries) and also Bayern Kapital (an organization managing the seed funds of the State of Bavaria) provided substantial venture capital to the start-up. In 2010, the start-up already had 14 employees and 14 customers across Europe, and by 2014 Bayern Kapital decided that Corrmoran did not require further financing. Whilst the initial impulse for the venture came directly out of the university (i.e. already at this stage a beneficial and unique role of the university can be identified in that the founders met at the university through a research project carried out at the university), the UTG made crucial contributions in the later venture phases. Specifically, Corrmoran benefited from the UTG by having access to a common laboratory of the highest standard to refine and test the technology. Furthermore, the UTG provided an environment supporting intensive exchanges with firms working in very similar market contexts. Corrmoran could capitalize on this, which was significant in helping the venture develop its own entrepreneurial processes. Because of this, the venture could build on the expertise of other firms, as well as accessing their business networks, in a unique way that would not have been possible without the UTG.

\subsection{Case 2: MBA sustainability management}

\subsubsection{University-linked support programme}

The motivation to set up the world's first MBA programme in corporate sustainability management at the Centre for Sustainability Management (CSM) was to educate "change agents for corporate sustainability". The need for this new programme was based on the perceived lack of impact of sustainable management education, as students took a long time to get into positions of influence or lacked sufficient sustainability knowledge.

Three inputs were considered essential for the programme: financial inputs for establishing and maintaining it, the development of teaching materials and the involvement of lecturers. The programme content was originally financed with EU support funding, and there was no funding from the university. The programme was founded in a rather isolated manner and encountered little resistance owing to a gap between the responsibilities and competence areas of the relevant faculties. That situation provided the necessary organizational space to innovate (Lee and Schaltegger 2014). The founders of the programme worked on the development of teaching materials for 2 years until they had material for around 1800 lecture hours to support a 1-year full time (or 2-year part-time) programme with on-campus lectures and e-learning-based distance courses.

External lecturers were acquired with the help of a group of four PhD students at the Centre. The curriculum was discussed with representatives from the corporate world and the programme was accredited 7 weeks before it commenced. The programme's success is largely the result of the very high levels of personal engagement of the founders and the research team at CSM involved in the MBA teaching and student service. To reduce bureaucratic obstacles in the general university administration, most administrative processes are managed directly at CSM. The curriculum has been continuously improved and enlarged since inception (Hesselbarth et al. 2015). The programme was developed as a continuous education blended learning programme (and thus did not affect the existing on-campus programmes). The MBA curriculum covers classes in sustainability management, specialized functions (e.g. sustainable production and sustainable strategy) as well as dedicated courses on sustainable entrepreneurship and sustainability innovation.

A unique feature of the programme is the projectbased learning in which the entire cohort solves sustainability-related problems during a 5-day on-site placement with a business partner. The programme started in 2003 with 27 students and now about 40 students are admitted annually. Approximately 450 students have graduated from the MBA programme, and a 
large alumni network with approximately 600 people (graduates, lecturers and students) has been established with a broad own network programme of regional meetings and other activities (Hesselbarth and Schaltegger 2014). Due to the distance learning and part-time nature of the programme, the part-time students can directly apply new skills to their jobs and transfer their developed competencies into their professional working environment. The possibility for immediate and continuous application and trial of new knowledge increases both the motivation of the students and their real-world impact during their studies. Some students have founded their own sustainable businesses for example in the solar industry, consulting, IT and manufacturing of energysaving devices with the related potential impact on the transformation of industries.

\subsubsection{Exemplary new venture}

The start-up IntelliSolar was founded in 2006 by a former student of the MBA Sustainability Management. The company now has more than 30 employees and plans, develops and invests in semi-large photovoltaic (PV) systems on industrial sites (larger than $200 \mathrm{~m}^{2}$ but smaller than large photovoltaic parks). As a general contractor, the start-up delivers projects for both small and large companies and for private investors who either have roof space or want to invest in PV. The one-stopshop principle is the main offer of IntelliSolar as a general contractor: the start-up takes responsibility for the project and connects all actors dealing with the different steps of planning, installing and maintaining PV systems. IntelliSolar takes care of all the planning steps from the vision to installation and grid connection, including the planning of energy storage systems and maintenance. The founder of IntelliSolar graduated with the MBA Sustainability Management in Lüneburg, which supported him in various ways: First, the project management core of the company requires dealing with different kinds of expertise. Managing inter- and transdisciplinary approaches, with experts from different disciplines and in interdisciplinary teams is a key topic of the MBA programme. Second, the alumni network of the MBA programme provided a platform of exchange with fellow students, some of whom became employees of the company. The founder formed a group of detailed knowledge of study collaborators in terms of their interests in and commitment to sustainability and also their strengths and particular area of expertise. Third, fellow
MBA students work as architects in construction and other types of firms, which provides contacts, information and potential business opportunities. Utilizing the available support means the company has established a national network and works with regional partners near the customers who do the actual installation and local maintenance. With this innovation, the company contributes to the diffusion of PV systems in the mid-range size of projects. While large projects are often delivered by large investment companies with professional expertise and small projects on single-family houses can be undertaken by local heating and solar installation craftsmen, mid-size projects on smaller industrial buildings have a large potential with regard to the number of buildings and roofs, but require expertise and local support. This is exactly the market gap IntelliSolar serves and for whose customers the company has developed specific solutions. In addition to its services as a general contractor, the company provides services and technologies to substantially reduce installation time and costs for PV systems. Based on a car shell technology from the automotive industry, the company offers the fast installation system iFIX. Recently, the company has expanded both geographically to Spain and Switzerland and in terms of its range of services, now including rainwater catchment systems and small sewage water treatment systems.

\subsection{Case 3: Eco-Venturing at Carl von Ossietzky University Oldenburg, Germany}

\subsubsection{University-linked support programme}

The University of Oldenburg, located in the north-west of Germany, has a long tradition in sustainability-related teaching and research. Its three-term non-consecutive master's programme in Renewable Energy started as early as 1987. Based on its tradition and specific competencies in sustainability-related teaching and research, the Department of Business Administration, Economics and Law decided to expand the sustainability master cluster and introduce a new master's programme in Sustainability Economics and Management (SEM) from 2005.

A 2-month research visit to the Bren School of Environmental Science and Management at the University of California, Santa Barbara in 2008, offered a professor of innovation management and sustainability the opportunity to learn about the university's pioneering study 
programme in Eco-Entrepreneurship, which had been introduced only a year prior to his arrival. The professor subsequently persuaded his department to introduce an eco-entrepreneurship major study course as a specialization in the SEM master's programme. Central to the specialization in eco-entrepreneurship is the awardwinning master's project module in Eco-Venturing which has been offered every winter semester since 2009 (Fichter et al. 2016). The aims of the EcoVenturing module are threefold: (1) To get students interested in entrepreneurial solutions to societal challenges, (2) to develop their entrepreneurial skills for sustainable entrepreneurship and (3) to develop sustainability-oriented business models in close cooperation with entrepreneurs and regional companies. Under the guidance of two professors and two coaches, four or five teams of between three and five students work with selected business partners to promote sustainable startup ideas which are intended to be both economically successful and contribute to sustainable development goals.

In order to support sustainability-orientated business model development, the concept of a Sustainable Business Canvas was developed and is now being used by the students (Tiemann and Fichter 2016). About 30\% of all students in the master's programme SEM participate in the Eco-Venturing module to develop competencies in eco-venturing and in starting green businesses. Since 2009 , a total of 170 students have worked on 44 different sustainable start-up ideas. Almost half of these sustainable business ideas (20) led to actual new firm creation or new business units in existing companies. The Eco-Venturing module is part of the entrepreneurial support system of the University of Oldenburg and the sustainability-specific support activities facilitate and accelerate academic entrepreneurship in the fields of clean technologies, renewable energies and sustainability. Every year, the programme supports students and researchers in the creation of between 10 and 20 green start-up projects and spin-offs (Fichter et al. 2016). To date, 20 new eco-ventures providing approximately 100 new jobs have been created since 2009 out of the EcoVenturing module.

\subsubsection{Exemplary new venture}

The start-up team from Coolar participated in the EcoVenturing module in the winter term of 2015/2016. By then, they had already developed a prototype for an innovative solar-powered refrigerator technology that was almost carbon neutral. They also had a business plan for applying the technology for a specific use case. The refrigerator was intended to enable doctors and health professionals to preserve lifesaving medicine and vaccines in a reliable and eco-friendly way in developing countries. The Coolar team was also considering the application of the technology for a self-powered truck temperature control solution. The student team involved aimed to analyse and assess the market for truck refrigeration. A key outcome of the EcoVenturing module was a report by the student team with a detailed competitor analysis, results from interviews with potential customers from the logistics sector and recommendations of promising market segments. This provided the Coolar team with a solid basis of information to facilitate business development. The work done in the Eco-Venturing module prompted Coolar to include a specific segment of the truck refrigeration market in its business model that was presented to investors. Coolar was formally founded as a new venture only a few months after the Eco-Venturing project and was able to attract venture capital. The contribution of the Eco-Venturing project was critical to the foundation of the company, because Coolar could prove to investors that it had thoroughly investigated promising market segments and identified potential customers and revenue options. After 2 years of technology development and testing, the seven team members of Coolar are presently preparing the market introduction of their revolutionary refrigeration technology. Two years after the Eco-Venturing project, the start-up team of Coolar considers the detailed competitor and market analysis provided by the Eco-venturing module students to be a valuable basis for company development and strategic decision making. Given the fact that the $\mathrm{CO}_{2}$ emissions are ten times lower than conventional cooling solutions, the scaling-up of their cooling solution in different markets and sectors is very likely to have a significant impact on regional and global sustainability.

\section{Comparative case analysis}

To assess regional sustainability impacts, we analyse cases comparatively in order to clarify the degree to which the university was the originator of the initiative, how it linked to public actors and generated 
knowledge spillovers and how regional impact was achieved (see below and Table 4).

Based on our literature review, we structure the comparative case analysis along the different categories developed by the theory of change. In these categories, we build on the entrepreneurial ecosystem and innovation system literatures to clarify and structure the inputs provided in each case in a systematic manner.

We then use the knowledge spillover theory of entrepreneurship as our framework to categorize different types of outputs that represent benefits from the programmes and to guide our interpretation when analysing specific start-up examples to illustrate in more detail how the programmes led to or supported the founding activities of specific individuals. Nevertheless, we find more convergence in terms of the outputs, outcomes and longer-term impacts across the three programmes, which we address in Section 6 of the paper.

A number of functions can be identified as inputs to entrepreneurial and innovation processes in each of the cases (see Table 4), but the combination of functions is different for each of them. This is related to the differing activity profiles, which create individual forms of the support provided. Overall, what can be learned from the comparative case analysis is that the three cases present different configurations of university-related support programmes for sustainable regional development. This reveals different paths and processes in order to strengthen sustainable entrepreneurial ecosystems, beyond the classic incubator, which for example Theodoraki et al. (2018) analysed empirically.

To illustrate, while the UTG is more of a classic incubator providing a mixture of indirect (e.g. finance and office space) and direct (e.g. university spin-offs moving into the UTG) university support, the idea generation and facilitation of the EcoVenturing case as a module is more early-stage with a stronger focus on influencing and supporting the idea and business model development. In comparison, the MBA is not a module like for example EcoVenturing, but a comprehensive sustainability education programme that provides support across a much broader range of themes and skills. The heterogeneity found in our comparative case analysis is an important insight that is developed upon in Section 6.

Comparing the three examples of firms that received support from our case programmes, we find clear evidence of knowledge spillovers from universities to start-ups as proposed by the knowledge spillover theory of entrepreneurship. More specifically, we find a diverse set of mechanisms governing how knowledge spilled over in these instances from the university either in the form of technology, market information, network access or entrepreneurial processes such as funding access, business model development or team formation. It also becomes clear that different types of knowledge matter simultaneously, but that their relative importance differs. For example, technology and entrepreneurial processes were particularly important to Corrmoran, whereas for IntelliSolar, it was network knowledge. Coolar's main gains were market information and input on entrepreneurial processes.

While these examples show that the programmes certainly contributed significantly to the development of the entrepreneurs in question, other support structures were important too. The case descriptions provided mention several specific features that can be identified individually as being a form of strategic resource provided to the ventures, in that the benefit could not be accessed through other support structures. However, it also becomes clear that such programme features are highly idiosyncratic and thus depend strongly on the specific combination of exemplary entrepreneurs and (overall) support structures, as has also been confirmed by Kolb and Wagner (2018) in the case of academic entrepreneurship generally. We can however state with confidence that such unique features of the programmes exist in most cases but differ across specific start-ups and probably also in terms of when they provide the greatest benefit. This aspect is elaborated upon in the next section, including from a more holistic perspective in terms of a configurational notion.

Furthermore, clearly, the impacts generated through the three examples cannot be fully assessed because all the firms have only recently entered the market. However, all three examples reveal that an initially mainly regional impact may extend considerably beyond the region in the longer term. This is the case for Corrmoran that was ultimately acquired in a trade sale by a larger incumbent that was active beyond the region. Similarly, IntelliSolar recently entered new markets in other countries. Finally, the business activities of Coolar were also aimed at the international market from the outset. This is an important insight, which we will expand upon in Section 6. 
Table 4 Comparative case analysis based on the logic model of the theory of change

\begin{tabular}{|c|c|c|c|c|c|}
\hline Programme & $\begin{array}{l}\text { Input: } \\
\text { functions provided }\end{array}$ & $\begin{array}{l}\text { Activities: } \\
\text { support provided }\end{array}$ & $\begin{array}{l}\text { Output: } \\
\text { benefit from } \\
\text { programme }\end{array}$ & $\begin{array}{l}\text { Outcome: } \\
\text { entrepreneurial activities }\end{array}$ & $\begin{array}{l}\text { Impact: } \\
\text { potential regional } \\
\text { benefit }\end{array}$ \\
\hline $\begin{array}{l}\text { UTG } \\
\text { Augsburg }\end{array}$ & $\begin{array}{l}\text { - Entrepreneurship } \\
\text { experimentation } \\
\text { - Incubation } \\
\text { - Resource } \\
\text { mobilization } \\
\text { - Networking }\end{array}$ & $\begin{array}{l}140 \text { supported firms since } \\
\text { 1998, of which approx. } 40 \\
\text { are internationally active }\end{array}$ & $\begin{array}{l}\text { - Support in } \\
\text { foundation } \\
\text { process of firms } \\
\text { and of regional } \\
\text { networks for } \\
\text { sustainability }\end{array}$ & $\begin{array}{l}\text { E.g. start-up Corrmoran } \\
\text { (crucial inputs for } \\
\text { technology and entre- } \\
\text { preneurial processes) }\end{array}$ & $\begin{array}{l}\text { - Institutionalization } \\
\text { of a learning and } \\
\text { networking space } \\
\text { for sustainable } \\
\text { development; } \\
\text { - Contribution to } \\
\text { regional cluster } \\
\text { activities } \\
\text { - New firm } \\
\text { foundation }\end{array}$ \\
\hline $\begin{array}{l}\text { MBA } \\
\text { Sustainabil- } \\
\text { ity } \\
\text { Manage- } \\
\text { ment }\end{array}$ & $\begin{array}{l}\text { - Influence on the } \\
\text { direction of } \\
\text { search } \\
\text { (sustainability) } \\
\text { - Combined } \\
\text { education in } \\
\text { sustainability } \\
\text { management, } \\
\text { innovation, and } \\
\text { entrepreneurship } \\
\text { - Interactive } \\
\text { learning }\end{array}$ & $\begin{array}{l}48 \text { courses (each } 30 \text { h); } \\
\text { transfer module; final } \\
\text { practice workshop; thesis; } \\
5 \text { courses dedicated to } \\
\text { entrepreneurship; } 8 \\
\text { courses with } \\
\text { entrepreneurship content } \\
\text { as part of the course; } 40 \\
\text { graduations per year since } \\
2005\end{array}$ & $\begin{array}{l}\text { - Support in new } \\
\text { eco-venture } \\
\text { founding } \\
\text { processes } \\
\text { - Support of } \\
\text { knowledge } \\
\text { transfer and } \\
\text { diffusion } \\
\text { processes }\end{array}$ & $\begin{array}{l}\text { E.g. start-up IntelliSolar } \\
\text { (crucial inputs for } \\
\text { venture-specific hu- } \\
\text { man capital of the } \\
\text { founder, networks for } \\
\text { business } \\
\text { development and } \\
\text { recruitment) }\end{array}$ & $\begin{array}{l}\text { - Acceleration of } \\
\text { decentralized } \\
\text { solar energy } \\
\text { production } \\
\text { - Acceleration of } \\
\text { energy } \\
\text { transformation } \\
\text { on the regional } \\
\text { level; } \\
\text { - New firm } \\
\text { foundation }\end{array}$ \\
\hline Eco-Venturing & $\begin{array}{l}\text { - Influence on the } \\
\text { direction of } \\
\text { search } \\
\text { - Entrepreneurship } \\
\text { education and } \\
\text { experimentation } \\
\text { - Incubation } \\
\text { - Resource } \\
\text { mobilization } \\
\text { - Networking }\end{array}$ & $\begin{array}{l}44 \text { supported green start-up } \\
\text { projects, incl. elaborated } \\
\text { sustainable business } \\
\text { models, and } 170 \text { students } \\
\text { with sustainable } \\
\text { entrepreneurship expertise } \\
\text { since } 2009\end{array}$ & $\begin{array}{l}\text { - Support of new } \\
\text { firm foundation } \\
\text { through } \\
\text { entrepreneurial } \\
\text { education } \\
\text { - Incubation and } \\
\text { acceleration of } \\
\text { sustainable } \\
\text { business ideas }\end{array}$ & $\begin{array}{l}\text { E.g. start-up Coolar (cru- } \\
\text { cial inputs to the ven- } \\
\text { ture's business case, } \\
\text { market and competitor } \\
\text { knowledge, and } \\
\text { business } \\
\text { development) }\end{array}$ & $\begin{array}{l}\text { - Reduction of } \\
\text { greenhouse gas } \\
\text { emissions } \\
\text { - Contribution to the } \\
\text { profile of the } \\
\text { region as having } \\
\text { a sustainable and } \\
\text { resilient } \\
\text { economy } \\
\text { - New firm } \\
\text { foundation }\end{array}$ \\
\hline
\end{tabular}

\section{Discussion and conclusions}

Based on the increasingly relevant third mission in regional and economic development that universities globally are urged to take on, this study builds on three case studies in Germany and analyses how universitylinked support programmes contribute to sustainable entrepreneurial ecosystems and which impacts this delivers for sustainable regional development. Our comparative case study analysis reveals a differentiated view of entrepreneurship-related interventions.

First of all, we find evidence addressing our research questions that sustainable entrepreneurial ecosystems are positively affected by university-linked support programmes through certain knowledge spillover modes.
For example, in the case of UTG Augsburg, the university's role as one instigator of the initiative was clear (along with the state of Bavaria, the local chamber of industry and commerce, and other actors). That role then triggered support by other actors. At the same time, the university also provided direct inputs, such as spin-offs that entered the incubator. Other spillover modes are the supply of entrepreneurial knowledge, incubation activities and support services for green start-ups through the EcoVenturing module. Also, the university provides knowledge spillovers to the entrepreneurial ecosystem via the system functions (Table 1) of influencing the direction of search, learning, resource mobilization and networking.

One major insight flowing from the current study is that university-linked support programmes can improve the 
entrepreneurial ecosystem for sustainable entrepreneurship through different pathways and at different intervention points. For example, interventions can be undertaken early as in the Eco-Venturing and MBA cases (which focus more on idea generation/identification and opportunity evaluation) or later as in the UTG case (which has a stronger focus on opportunity exploitation and incubation).

One main reason emerging from the cases for the possibility of different pathways and roles of universities is that universities operate under specific regional conditions and therefore choose and enable specific roles or pathways, and also determine intervention points that best fit such conditions. As a result, different types or configurations that develop as stable outcomes of such a fitting process are identifiable. Ultimately, context thus plays an important role for any university-linked support programme. In our cases, for example, the cluster programme in Bavaria and the strong civil society inherent in the "peace city" Augsburg, which has a strong emphasis on local Agenda 21 processes and networking, shaped the UTG activities.

In contrast, Lower Saxony lacks comparable top-down initiatives, meaning local bottom-up initiatives gain more freedom to operate and at the same time a stronger need to provide substitutes for critical elements of the support programmes that are provided through the cluster management in Bavaria. These differences between the two states suggest that different configurations of university-linked support programmes can emerge depending on how context and the conditions at the university interplay and replace or complement each other to facilitate the system functions necessary to drive improvements of the regional ecosystem supporting sustainable entrepreneurship. This nuanced view is important for a better understanding of the potential and role that universities have in supporting sustainable entrepreneurship ecosystems.

Our comparative analysis based on the theory of change and the entrepreneurial ecosystem model by Stam and Spigel (2016) was applied to determine positive effects on sustainable development in the region. The analysis revealed both direct and short-term outputs in terms of entrepreneurial activity and less direct, broader long-term outcomes. The tangible direct outputs include both specific examples of successful ventures and more general contributions to sustainable development in the region (see Table 4).

We further contribute by expanding the analysis of barriers and success factors affecting how universities can support sustainable entrepreneurship and of how support programmes could be actioned (e.g. Fichter and Tiemann 2018). The study also shows how such programmes trigger sustainable regional development outputs, outcomes and impacts, which addresses a gap in the literature. Depending on the context, what may be considered a barrier can become an opportunity as in the case of the MBA programme where the lack of a specific support system has created space and incentives to become entrepreneurial and use a window of opportunity to establish the MBA. In turn, the MBA itself created a support programme and offered the incentives and knowledge necessary to found a company (IntelliSolar). Specific positive impacts that can be identified in our cases are a reduction of greenhouse gas emissions (by increasing the proportion of energy generated through renewable means in the region), the provision of additional employment with lower health risks and the intensification knowledge spillovers in regional networks, as well as the internalization of externalities flowing from improvements to knowledge and social feedback loops. The latter can also be seen as the emergence of new capabilities in the region that make it more resilient and sustainable.

The cases presented here also illustrate the potential for long-term effects. Clearly, what starts as a purely regional impact can subsequently exert an effect extending considerably beyond the original region, especially when sustainable regional development is successful. This expansion of effect may mean that the creating region does not retain the largest share of the benefits but equally that a smaller share of a bigger benefit ultimately still makes a strong regional impact. This suggests that even start-ups that do not target significant regional impacts but making a strong positive impact on sustainable development at the national or global level can ultimately substantially benefit a region - a dual regional paradox that merits further exploration.

Related to this insight, while the linear logic model applied in first approximation covers the most important causalities to answer our research question, we urge future research to explore non-linear extensions to the framework to address this potential limitation. For example, within our chosen context, future research might comprehensively assess impacts, which would also support an improved assessment of long-term effects.

Building on above insights, in terms of the broader question of how and with what impact university-linked programmes can support sustainable entrepreneurial ecosystems, both directly and indirectly, we exposed strong evidence that universities taking on a third 
mission prompts crucial activities that overcome knowledge filter issues (Braunerhjelm et al. 2010). In doing so, they ultimately enable and improve important ecosystem functions supporting sustainable entrepreneurship. This occurs for example in terms of not only providing education and learning as a basis for knowledge spillovers, but also through more complex and potentially less direct knowledge spillovers, such as the generation of spin-offs.

Our findings have implications for policy-makers and academics. Clearly, a sustainability focus in university-linked support programmes can play an important role in fostering sustainable entrepreneurial ecosystems and sustainable regional development. The cases analysed in our sample all represent programmes with an explicit sustainability focus that is an element of institutional entrepreneurship; a finding that responds to calls in the literature for more research in this area (Hall et al. 2010). Conventional entrepreneurship support, however, though increasingly available with the involvement of universities, typically lacks such a sustainability focus (Theodoraki et al. 2018; Tiemann et al. 2018).

Relating our findings back to our conceptual foundations in terms of the knowledge spillover theory of entrepreneurship, entrepreneurial ecosystems and the theory of change, we find strong evidence of a process involving different actors providing inputs as the basis for activities that ultimately generate functions in order to achieve effects at different levels (outputs, outcomes and impacts). We also identified different feasible configurations based on region-specific fit and substitution options. Identifying the possibility of universities using different pathways and intervention points is an important insight that policymakers should take into account and that deserves further attention in academic research.

At the same time, an important implication for universities wishing to become involved in support programmes for sustainable entrepreneurial ecosystems is that they should analyse their specific regional context to ensure that their chosen configuration and design (e.g. in terms of intervention points, roles or pathways) fit the specific regional situation in the best possible way. This applies equally to support programmes with a more environmental focus or those with a more social focus. In turn, successful implementation of regional strategies can ultimately have strong positive impacts beyond the region. Both universities and (regional) policy-makers should take this wider impact into account at the outset.
Doing so would enable them to set realistic expectations for the regional development results they target. To conclude, our article addresses calls to research more on the process and effect dimensions of (sustainable) entrepreneurial ecosystems (Agarwal et al. 2007, 2010; Stam and Spigel 2016). In particular, our case-based analysis contributes by highlighting different configurations of university-linked programmes supporting sustainable entrepreneurial ecosystems. In doing so, we complement and extend work focussing on specific configurations and front-ends of sustainable entrepreneurial ecosystems (e.g. Theodoraki et al. 2018; Fichter and Tiemann 2018). Overall, our paper should therefore extend understanding of the pathways available for universities to support sustainable entrepreneurial ecosystems by enabling knowledge spillovers and the impact doing so can have on sustainable regional development.

Acknowledgements We are grateful to our colleague Markus Beckmann for valuable inputs and discussions during the earlier stages of this project and the corresponding paper, as well as for beneficial comments from the participants at the G-Forum 2017 in Wuppertal and from two anonymous reviewers. Erik Hansen furthermore thanks Quality Austria - Trainings, Zertifizierungs und Begutachtungs GmbH, Vienna and the State of Upper Austria for their funding of the Institute for Integrated Quality Design.

Funding Information Open access funding provided by Johannes Kepler University Linz.

Open Access This article is distributed under the terms of the Creative Commons Attribution 4.0 International License (http:// creativecommons.org/licenses/by/4.0/), which permits unrestricted use, distribution, and reproduction in any medium, provided you give appropriate credit to the original author(s) and the source, provide a link to the Creative Commons license, and indicate if changes were made.

\section{References}

Abdelkafi, N., \& Hansen, E. G. (2018). Ecopreneurs' creation of user business models for green tech: an exploratory study in Emobility. International Journal of Entrepreneurial Venturing, 10(1), 32-55. https://doi.org/10.1504/IJEV.2018.10007848.

Abreu, M., Demirel, P., Grinevich, V., \& Karatas-Özkan, M. (2016). Entrepreneurial practices in research-intensive and teaching-led universities. Small Business Economics, 47, 695-717. https://doi.org/10.1007/s11187-016-9754-5.

Agarwal, R., Audretsch, D., \& Sarkar, M. B. (2007). The process of creative construction: knowledge spillovers, entrepreneurship, and economic growth. Strategic Entrepreneurship Journal, 1, 263-286. https://doi.org/10.1002/sej.36.

Agarwal, R., Audretsch, D., \& Sarkar, M. B. (2010). Knowledge spillovers and strategic entrepreneurship. Strategic 
Entrepreneurship Journal, 4(4), 271-283. https://doi. org/10.1002/sej.96.

Anon. (2018). https://www.plattform-ressourceneffizienz. de/angebot/dr-viola-rueckert/. Accessed 11 July 2018.

Anon. (2011). Umwelt-Technologie und Energie in Bayern. Munich: media mind $\mathrm{GmbH}$.

Audretsch, D., \& Belitski, M. (2017). Entrepreneurial ecosystems in cities: establishing the framework conditions. Journal of Technology Transfer, 42(5), 1030-1051. https://doi.org/ $10.1007 / \mathrm{s} 1096101694738$.

Audretsch, D., \& Berlitski, M. (2013). The missing pillar: the creativity theory of knowledge spillover entrepreneurship. Small Business Economics, 41, 819-836. https://doi. org/10.1007/s11187-013-9508-6.

Bank, N., Fichter, K., \& Klofsten, M. (2017). Sustainabilityprofiled incubators and securing the inflow of tenants - the case of Green Garage Berlin. Journal of Cleaner Production, 157, 76-83.

Binder, J. K., \& Belz, F. M. (2015). Sustainable entrepreneurship: what it is. In P. Kyrö (Ed.), Handbook of entrepreneurship and sustainable development research (pp. 30-75). Cheltenham: Edward Elgar Publishing.

Boons, F., Montalvo, C., Quist, J., \& Wagner, M. (2013). Sustainable innovation, business models and economic performance: an overview. Journal of Cleaner Production, 45, 1-8. https://doi.org/10.1016/j.jclepro.2012.08.013.

Braunerhjelm, P., Acs, Z., Audretsch, D., \& Carlsson, B. (2010). The missing link: knowledge diffusion and entrepreneurship in endogenous growth. Small Business Economics, 34, 105125. https://doi.org/10.1007/s11187-009-9235-1.

Carman, J. G. (2010). The accountability movement: what's wrong with this theory of change? Nonprofit and Voluntary Sector Quarterly, 39(2), 256-274. https://doi.org/10.1177 /0899764008330622.

Cohen, B. (2006). Sustainable valley entrepreneurial ecosystems. Business Strategy and the Environment, 15(1), 1-14. https://doi.org/10.1002/bse.428.

Cohen, B., \& Winn, M. I. (2007). Market imperfections, opportunity and sustainable entrepreneurship. Journal of Business Venturing, 22(1), 29-49. https://doi.org/10.1016/j. jbusvent.2004.12.001.

Eisenhardt, K. M. (1989). Building theories from case study research. Academy of Management Review, 14(4), 532-550.

Epstein, M. J., \& Roy, M.-J. (2001). Sustainability in action: identifying and measuring the key performance drivers. Long Range Planning, 34(5), 585-604. https://doi. org/10.1016/S0024-6301(01)00084-X.

Etzkowitz, H., \& Klofsten, M. (2005). The innovating region: toward a theory of knowledge-based regional development. R\&D Management, 35(3), 243-255.

Etzkowitz, H., \& Leydesdorff, L. (2000). The dynamics of innovation: from National Systems and "mode 2" to a triple Helix of university-industry-government relations. Research Policy, 29(2), 109-123. https://doi.org/10.1016/S0048-7333 (99)00055-4.

Fichter, K., \& Tiemann, I. (2018). Factors influencing university support for sustainable entrepreneurship - insights from explorative case studies. Journal of Cleaner Production, 175, 512-524. https://doi.org/10.1016/j.jclepro.2017.12.031.
Fichter, K., Geier, J., \& Tiemann, I. (2016). Good practice collection - university support for sustainable entrepreneurship. Berlin, Helsinki, Linköping: SHIFT.

Funnel, S. C., \& Rogers, P. J. (2011). Purposeful program theory: effective use of theories of change and logic models. London: Wiley.

Gast, J., Gundolf, K., \& Cesinger, B. (2017). Doing business in a green way: a systematic review of the ecological sustainability entrepreneurship literature and future research directions. Journal of Cleaner Production, 147, 44-56.

Geier, J., \& Fichter, K. (2015). Good practice examples: activities in sustainable entrepreneurship at universities in Finland, Germany, Sweden, the United Kingdom and the United States. Berlin, Helsinki, Linköping: SHIFT.

Glaser, B., \& Strauss, A. (1967). The discovery of grounded theory: strategies in qualitative research. London: Wiedenfeld and Nicholson.

Hall, J. K., Daneke, G. A., \& Lenox, M. J. (2010). Sustainable development and entrepreneurship: past contributions and future directions. Journal of Business Venturing, 25(5), 439-448. https://doi.org/10.1016/j.jbusvent.2010.01.002.

Hansen, E. G., \& Schaltegger, S. (2016). The sustainability balanced scorecard: a systematic review of architectures. Journal of Business Ethics, 133, 193-221.

Hansen, E. G., \& Spitzeck, H. (2011). Measuring the impacts of NGO partnerships: the corporate and societal benefits of community involvement. Corporate Governance: International Journal of Business in Society, 11(4), 415426. https://doi.org/10.1108/14720701111159253.

Hansen, E. G., Sextl, M., \& Reichwald, R. (2010). Managing strategic alliances through a community-enabled balanced scorecard: the case of Merck Ltd, Thailand. Business Strategy and the Environment, 19(6), 387-399. https://doi. org/10.1002/bse.689.

Hehl, W. (2010). Die bayerische Clusterstrategie und die Rolle des Umwelt-Technologischen Gründerzentrums Augsburgs (UTG), Presentation at Julius-Maximilians-University Wuerzburg, 17 November.

Hehl, W. (2011). Umwelttechnologie: Luxus in einer Nische oder globale Notwendigkeit und ökonomische Chance?, Presentation at Julius-Maximilians-University Wuerzburg, 15 November.

Hesselbarth, C., \& Schaltegger, S. (2014). Educating change agents for sustainability. Learnings from the first sustainability management master of business administration. Journal of Cleaner Production, 62, 24-36. https://doi.org/10.1016/j. jclepro.2013.03.042.

Hesselbarth, C., Buhr, M., \& Schaltegger, S. (2015). Management education for sustainability. Deriving learning formats from competency requirements. In P. J. Davim (Ed.), Sustainability in higher education (pp. 21-49). Burlington: Elsevier.

Hockerts, K., \& Wüstenhagen, R. (2010). Greening goliaths versus emerging Davids - theorizing about the role of incumbents and new entrants in sustainable entrepreneurship. Journal of Business Venturing, 25(5), 481-492. https://doi. org/10.1016/j.jbusvent.2009.07.005.

Holt, D., \& Watson, A. (2008). Exploring the dilemma of local sourcing versus international development - the case of the flower industry. Business Strategy and the Environment, 17(5), 318-329. https://doi.org/10.1002/bse.623. 
Kolb, C., \& Wagner, M. (2018). Different breeds, different needs: How university spin-offs differ in composition and interaction - a qualitative approach. Journal of Technology Transfer, 43(3), 734-759.

Kuckertz, A., \& Wagner, M. (2010). The influence of sustainability orientation on entrepreneurial intentions - investigating the role of business experience. Journal of Business Venturing, 25(5), 524-539. https://doi.org/10.1016/j.jbusvent.2009.09.001.

Lee, K. H., \& Schaltegger, S. (2014). Organizational transformation and higher sustainability management education. The case of the MBA sustainability management. International Journal of Sustainability in Higher Education, 15(4), 450471. https://doi.org/10.1108/IJSHE-06-2013-0067.

London Benchmarking Group (LBG) (2004). Measure for measure: celebrating the LBG's first ten years. London. Retrieved from http://www.lbg-online.net/var/news/storage/original/application/ ef7704e14e3c1ba07876310b1b1a1eed.pdf. Accessed 21 May 2008.

Markard, J., \& Truffer, B. (2008). Technological innovation systems and the multi-level perspective: towards an integrated framework. Research Policy, 37(4), 596-615. https://doi. org/10.1016/j.respol.2008.01.004.

Marshall, A. (1920). Principles of economics. London: Macmillan.

McLaughlin, J. A., \& Jordan, G. B. (1999). Logic models: a tool for telling your programs performance story. Evaluation and Program Planning, 22(1), 65-72. https://doi.org/10.1016 /S0149-7189(98)00042-1.

Miles, M. B., \& Huberman, A. M. (1994). Qualitative data analysis: an expanded sourcebook. Thousand Oaks/London: Sage.

Ney, S., Beckmann, M., Graebnitz, D., \& Mirkovic, R. (2014). Social entrepreneurs and social change: tracing impacts of social entrepreneurship through ideas, structures and practices. International Journal of Entrepreneurial Venturing, 6(1), 51-68.

OECD. (2002). Glossary of key terms in evaluations and results based management. Paris: OECD.

Pacheco, D. F., Dean, T. J., \& Payne, D. S. (2010). Escaping the green prison: entrepreneurship and the creation of opportunities for sustainable development. Journal of Business Venturing, 25, 464-480.

Parrish, B. D. (2010). Sustainability-driven entrepreneurship: principles of organization design. Journal of Business Venturing, 25, 510-523. https://doi.org/10.1016/j.jbusvent.2009.05.005.

Porter, M. E., Delgado, M., \& Stern, S. (2010). Clusters and entrepreneurship. Boston: Harvard Business School.

Rothaermel, F. T., Agung, S. D., \& Jiang, L. (2007). University entrepreneurship: a taxonomy of the literature. Industrial and Corporate Change, 16(4), 691-791. https://doi.org/10.1093 icc/dtm023.

Schaltegger, S., \& Wagner, M. (2011). Sustainable entrepreneurship and sustainability innovation: categories and interactions. Business Strategy and the Environment, 20(4), 222237. https://doi.org/10.1002/bse.682.

Schaltegger, S., Lüdeke-Freund, F., \& Hansen, E. (2016). Business models for sustainability. A co-evolutionary analysis of sustainable entrepreneurship, innovation and transformation. Organization \& Environment, 29(3), 264-289.

Schaltegger, S., Beckmann, M., \& Hockerts, K. (2018). Sustainable entrepreneurship: creating environmental solutions in light of planetary boundaries. International Journal of Entrepreneurial Venturing, 10(1), 1-16.

Sedlacek, S. (2013). The role of universities in fostering sustainable development at the regional level. Journal of Cleaner Production, 48, 74-84.

Shane, S. A., \& Eckhardt, J. T. (2003). The individual-opportunity nexus. In Z. J. Ács \& D. B. Audretsch (Eds.), International handbook series on entrepreneurship: Vol. 1. Handbook of entrepreneurship research. An interdisciplinary survey and introduction (pp. 161-191). Boston: Kluwer.

Shepherd, D. A., \& Patzelt, H. (2011). The new field of sustainable entrepreneurship: studying entrepreneurial action linking 'what is to be sustained' with 'what is to be developed'. Entrepreneurship Theory and Practice, 35(1), 137-163. https://doi.org/10.1111/j.1540-6520.2010.00426.x.

Simatupang, T. M., Schwab, A., \& Lantu, D. C. (2015). Introduction: building sustainable entrepreneurship ecosystems. Editorial. International Journal of Entrepreneurship and Small Business, 26(4), 389-398.

Stam, E. (2015). Entrepreneurial ecosystems and regional policy: a sympathetic critique. European Planning Studies, 23(9), 17591769. https://doi.org/10.1080/09654313.2015.1061484.

Stam, E., \& Spigel, B. (2016). Entrepreneurial ecosystems (Vol. 13). Utrecht: Utrecht School of Economics.

Theodoraki, C., Messeghem, K., \& Rice, M. P. (2018). A social capital approach to the development of sustainable entrepreneurial ecosystems: an explorative study. Small Business Economics, 51, 153-170. https://doi.org/10.1007/s11187017-9924-0.

Thierstein, A., \& Walser, M. (1997). Sustainable regional development the squaring of the circle or a gimmick? Entrepreneurship and Regional Development, 9(2), 159174. https://doi.org/10.1080/08985629700000008.

Tiemann, I., \& Fichter, K. (2016). Developing business models with the sustainable business canvas: manual for conducting workshops. Oldenburg: University of Oldenburg Retrieved from www.borderstep.de. Accessed 27 August 2019.

Tiemann, I., Fichter, K., \& Geier, J. (2018). University support systems for sustainable entrepreneurship: insights from explorative case studies. International Journal of Entrepreneurial Venturing, 10(1), 83-110.

United Nations (2015). Transforming our world: the 2030 agenda for sustainable development. Resolution No. A/RES/70/1. http://www.un.org/ga/search/viewdoc.asp?symbol= A/RES/70/1\&Lang=E.. Accessed 26 Aug 2019.

Wagner, M. (2012). Ventures for the public good and entrepreneurial intentions: an empirical analysis of sustainability orientation as a determining factor. Journal of Small Business and Entrepreneurship, 25(4), 519-532. https://doi. org/10.1080/08276331.2012.10593587.

Wagner, M., \& Lutz, E.-M. (2012). Sustainability-improving innovation: empirical insights and relationships with sustainability-oriented entrepreneurship. In M. Wagner (Ed.), Entrepreneurship, innovation and sustainability (pp. 279-296). Sheffield: Greenleaf.

Wagner, M., \& Schaltegger, S. (2010). Classifying entrepreneurship for the public good: empirical analysis of a conceptual framework. Journal of Small Business and Entrepreneurship, 23(3), 431-443. https://doi.org/10.1080/08276331.2010.10593494. 
Yin, R.K. (2003). Case study research: Design and methods (3rd ed). Applied social research methods series (Vol. 5). Thousand Oaks: Sage.
Publisher's note Springer Nature remains neutral with regard to jurisdictional claims in published maps and institutional affiliations. 